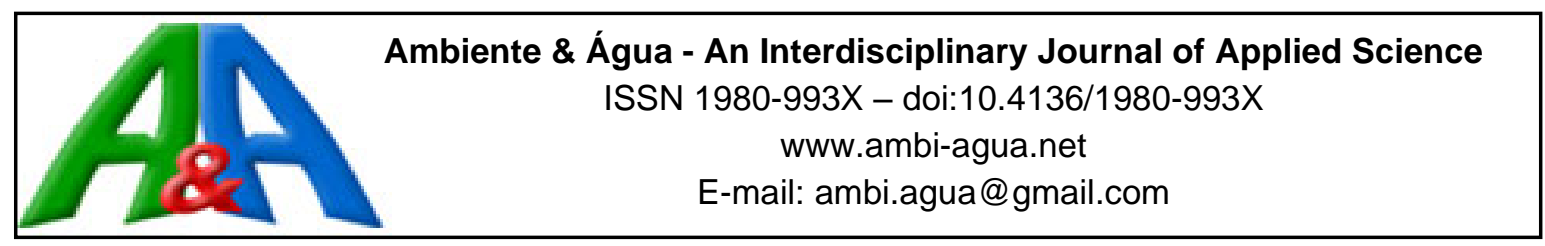

\title{
Performance of a small-scale construction and demolition waste recycling unit: a case study in northeastern Brazil
}

\author{
ARTICLES doi:10.4136/ambi-agua.2691
}

Received: 30 Dec. 2020; Accepted: 10 Jun. 2021

\section{Laís Carlos Boaventura Santos' ${ }^{1}$; Thaís Andrade de Sampaio Lopes $^{2}$; Luciano Matos Queiroz $^{3 *}$; Viviana Maria Zanta ${ }^{1}$ (D)}

\begin{abstract}
${ }^{1}$ Departamento de Engenharia Ambiental. Universidade Federal da Bahia (UFBA), Rua Aristides Novis, $\mathrm{n}^{\circ} 2$ CEP: 40210-630, Salvador, BA, Brazil. E-mail: laisc.boaventura@gmail.com, zanta@ufba.br

${ }^{2}$ Área técnica de Meio Ambiente. Instituto Federal de Educação, Ciência e Tecnologia Baiano (IF Baiano), Campus Itapetinga, Km 02, CEP: 45700-000, Itapetinga, BA, Brazil. E-mail: lopestas@gmail.com

${ }^{3}$ Escola Politécnica. Departamento de Engenharia Ambiental. Universidade Federal da Bahia (UFBA), Rua Aristides Novis, n², CEP: 40210-630, Salvador, BA, Brazil.

*Corresponding author. E-mail: lmqueiroz@ufba.br
\end{abstract}

\begin{abstract}
Environmental and operational performance of a full-scale small and decentralized construction and demolition waste (C\&DW) recycling unit (SDRU) were evaluated. The SDRU was defined as having a production capacity of up to $5 \mathrm{~m}^{3}$ per hour, occupying up to $100 \mathrm{~m}^{2}$. The operational and environmental performance indicators of the SDRU were obtained from the literature and validated by expert judgment. Subsequently, the values of these indicators were obtained from a real-scale SDRU in Bahia state, Brazil. The results showed that the SDRU presented lower levels of noise emission, very small water and energy consumption, and inhalable-particle concentration values lower than the requirements of Brazilian environmental legislation. It was observed that $90 \%$ of the C\&DW in the storage area had recycling potential. The characteristics of the fine recycled aggregate make it suitable for use in road or sidewalk paving, and the coarse recycled aggregate is suitable for use in concrete without structural function. A Life Cycle Assessment (LCA) of the SDRU was also applied and it was concluded that the use of the recycled aggregate for manufacturing concrete without structural function reduced the environmental impact in all the categories considered, compared with the impact of natural sand and gravel extraction from nature. It was possible to conclude that the implementation of the SRDU in developing countries can provide an effective step towards reducing environmental impacts from the construction sector.
\end{abstract}

Keywords: construction sector, environmental impacts, industrial ecology.

\section{Performance de Unidade de Pequeno Porte para Reciclagem de Resíduos da Construção e Demolição: Um estudo de caso na região nordeste do Brasil}

\section{RESUMO}

Avaliou-se o desempenho operacional e ambiental de uma unidade descentralizada e de pequeno porte (UDR) para a promoção da reciclagem de resíduos da construção e demolição (RCD). A UDR foi definida como aquela capaz de reciclar até $5 \mathrm{~m}^{3}$ por hora e ocupando uma 
área inferior a $100 \mathrm{~m}^{2}$. Os indicadores de avaliação de desempenho foram obtidos por meio de ampla revisão de literatura e selecionados pelo julgamento de especialistas na área. Após essa etapa, obtiveram-se os valores desses indicadores em uma UDR implantada em escala real no estado da Bahia, Brasil. Os resultados mostraram que a UDR apresenta pequenos níveis de emissão de ruídos, consumo de água e energia. Ademais, os valores de emissão de concentração de partículas inaláveis foram sempre inferiores aos máximos permitidos na legislação ambiental brasileira. Observou-se que $90 \%$ dos RCD devidamente segregados possuíam potencial para reciclagem. Uma Avaliação de Ciclo de Vida (ACV) da UDR foi realizada e permitiu concluir que o uso do agregado reciclado para produção de concreto sem função estrutural reduziu significativamente o impacto ambiental em todas as categorias selecionadas. As características do agregado reciclado atestam sua adequabilidade para uso em obras de pavimentação e fabricação de concreto sem função estrutural. Além dos reduzidos custos de investimento e operação, concluiu-se que a implementação dessas UDR em larga escala, nos países em desenvolvimento, pode ser uma importante iniciativa, representando um passo efetivo para redução dos impactos ambientais oriundos do setor de construção.

Palavras-chave: ecologia industrial, impactos ambientais, setor da construção.

\section{INTRODUCTION}

The atmospheric $\mathrm{CO}_{2}$ levels are already close to the last seen around four million years ago, in the Pliocene epoch. It is rapidly heading towards levels last seen some 50 million years ago when temperatures were up to $14^{\circ} \mathrm{C}$ higher than they were in pre-industrial times (Lenton et al., 2020). When the $21^{\text {st }}$ Conference of the Parties (or "COP21") to the United Nations Framework Convention on Climate Change (UNFCCC) was held in Paris, 195 countries adopted the first global climate deal, which came into effect in 2020. These continuous timelines to meet global/national goals to reduce emissions require support from industries such as the construction sector (Sergeeva and Lindkvist, 2019).

The construction and maintenance of the urban environment represent the largest resource footprint, with $42.4 \mathrm{Gt}$ consumed annually, equivalent to almost $50 \%$ of global material consumption and $20 \%$ of global greenhouse gas (GHG) emissions (Circle Economy, 2019). Hertwich et al. (2019) stated that the most important uses of materials in terms of embodied GHG emissions in the construction sector are lime, plaster and cement (2.9 $\mathrm{Gt}_{\mathrm{CO}}$ eq.). The authors also estimated that materials contribute over $50 \%$ of the carbon footprint of buildings and infrastructure, and around $40 \%$ of GHG emissions from total material manufacturing originate in the production of materials used in construction (Hertwich et al., 2019)..

Jiménez-Rivero and García-Navarro (2017), studying data from European Union (EU) members, concluded that around $10-15 \%$ of construction materials are wasted and $54 \%$ of demolition materials are landfilled because they are unsuitable for reuse due to their toxicity. The projections are alarming. The same authors warn that a billion tons of construction and demolition waste, with half of it being excavation material, is expected to be produced annually from 2020 onwards at the EU level.

The construction sector in developing countries is usually one of the three most relevant economic sectors, mainly due to its capability to boost the economy and generate jobs and income. In India, the annual investment in construction activities is around $\$ 70$ billion and an additional investment of $\$ 50$ billion is expected for an annual growth rate of $15 \%$ (Kolaventi et al., 2019). Ponnada and Kameswari (2016) estimated that the material requirement for the housing sector requires 55,000 million $\mathrm{m}^{3}$, whereas the road sector requires an additional quantity of 750 million $\mathrm{m}^{3}$. In Brazil, despite the negative effects of the pandemic caused by COVID-19, the sector employed 6.38 million people in 2020. The construction segment is the 
one that has the greatest impact on the total persons employed in this sector. In the first quarter of 2020 , it accounted for $55.9 \%$ of the total.

Considering the Brazilian territory, an annual C\&DW generation of approximately 38 million cubic meters (calculations taking into account specific mass value of $1,200 \mathrm{~kg} \cdot \mathrm{m}^{-3}$ ) was estimated at the end of 2016. The Brazilian Sanitation Information System reports that information regarding the flow of C\&DW in 2016 is lacking and precarious, but reports show that $690,000 \mathrm{~m}^{3}$ were sent for recycling, which represents only $2 \%$ of the estimated C\&DW generation (IBGE, 2015).

In Brazil, the C\&DW management guidelines are defined by the National Solid Waste Policy, Law 12305/2010 and Directive 307/2002 published by the National Environmental Council (Brasil, 2010; Conama, 2002). These regulations stipulate that municipalities must have a C\&DW management plan and provide the facilities to collect and recover the waste produced by small generators that produce between 1.0 and $3.0 \mathrm{~m}^{3}$ per day. The big waste generators in Brazil are responsible for the management and final destination of the C\&DW produced in their own industries or companies. The low percentage of recycling in Brazil indicates that both small and large generators dispose of their waste inappropriately, causing severe environmental impacts.

According to Brazilian Technical Standards (ABNT, 2004), C\&DW are classified according to their potential use or destination. C\&DW Class A consists of mortar, concrete and ceramic materials, which have the potential to be recycled and reused in many different ways during the construction of buildings, roads and sidewalks, for example.

Most of the recycling facilities in Brazil had a nominal processing capacity of between 5,000 and 10,000 cubic meters of aggregates per month using crushing equipment with a nominal capacity of 25 to 50 cubic meters per hour (IBGE, 2015). Big processing facilities are the most commonly used in Brazil and only $20 \%$ are of the mobile type, with a production capacity of up to 100 tons per hour (CONAMA, 2002). Mobile and small units are not generally used and some barriers need to be overcome to enable their large-scale implementation. During informal and preliminary investigations (data not shown), some strongly held opinions were found that these units produce poor quality aggregates, and can generate unacceptable levels of noise and dust for nearby residential areas. The lower implementation cost of these units may not compensate for their low productivity and the unattractive selling prices of the recycled aggregate (Fatta et al., 2003).

The implementation of these small and mobile recycling units in Brazil and developing countries by public entities or private investors still faces many challenges and uncertainties, such as the environmental regulation for C\&DW management, the conflicting perceptions of different professionals, economic aspects (costs and benefits) and excessive bureaucracy (Huang et al., 2019). In addition, most of the studies published in the literature on C\&DW recycling units and their performance apply to medium and large ones, which have more than one processing stage and use robust equipment occupying large areas.

Therefore, considering the gap of technical information, this paper aims to present indicators of environmental and operational performance that are suitable for smaller and decentralized C\&DW recycling units and to get their values in a full-scale site. The environmental gains related to the SDRU operation were estimated using the Life Cycle Assessment (LCA) approach.

The mobile SDRU in this paper was defined as having a production capacity of up to $5 \mathrm{~m}^{3}$ per hour, occupying up to $100 \mathrm{~m}^{2}$. The equipment and devices used are transportable, easy to operate, and require only one employee to run. Thus, the premise was also adopted that this option is, in essence, a decentralized alternative for C\&DW valorization, with its installation being possible close to the source of generation, and also as a reception point for small volumes of C\&DW. 


\section{MATERIAL AND METHODS}

\subsection{Description of the SDRU}

The SDRU is located at a construction site in the Bahia state, Brazil (-12.264492 S, $38.925995 \mathrm{~W})$. The C\&DW generation source was a construction site of 20 low-income apartment buildings occupying a total area of $36,511.19 \mathrm{~m}^{2}$. The construction method adopted was structural masonry with precast slab. Table 1 shows the main characteristics of the SDRU installed on the construction site and of the equipment (Queixada 200P) used to grind the C\&DW.

Table 1. Main characteristics of the SDRU and of the crushing equipment (Queixada 200P).

\begin{tabular}{lc}
\hline Description & Characteristics \\
\hline Effective area & $85 \mathrm{~m}^{2}$ \\
Dimensions of the C\&DW storage bay & $6.2 \times 3.8 \times 1.7 \mathrm{~m}$ \\
Dimensions of fine recycled aggregate storage bay & $4.0 \times 4.1 \times 1.7 \mathrm{~m}$ \\
Dimensions of coarse recycled aggregate storage bay & $4.0 \times 3.7 \times 1.7 \mathrm{~m}$ \\
Dimensions of the ramp for manual transport of C\&DW & $3.8 \mathrm{~m}($ length): $1.0 \mathrm{~m}$ (height) \\
Height of the equipment considering the device for collecting the aggregate & $1.4 \mathrm{~m}$ \\
Nominal capacity & $1.1 \mathrm{~m}^{3}$ per hour \\
Energy consumption & $3.0 \mathrm{~kW}$ per hour \\
\hline
\end{tabular}

The SDRU, located outside the construction area at a distance of approximately $200 \mathrm{~m}$, was conceived to receive C\&DW from unusable blocks and concrete without structural function, in order to obtain recycled aggregates of better quality, although the equipment used is suitable for recycling all C\&DW classified as Class A (CONAMA, 2002). However, if the segregation and transportation were not carried out properly, other types of waste or contaminants could reach the storage area. The sorting and segregation of C\&DW was done manually at the construction site. The crusher (Queixada 200p) was located approximately $1.6 \mathrm{~m}$ above the ground. Therefore, the recycled aggregates produced could be transferred by gravity to the aggregate storage bays avoiding the installation of conveyor belts and energy consumption. The layout (Figure 1) of the recycling unit comprises a storage bay for the C\&DW Class A, the recycling equipment, an access ramp to transport the waste from the storage area to the recycling equipment, a cover and the storage bays for the recycled aggregates.

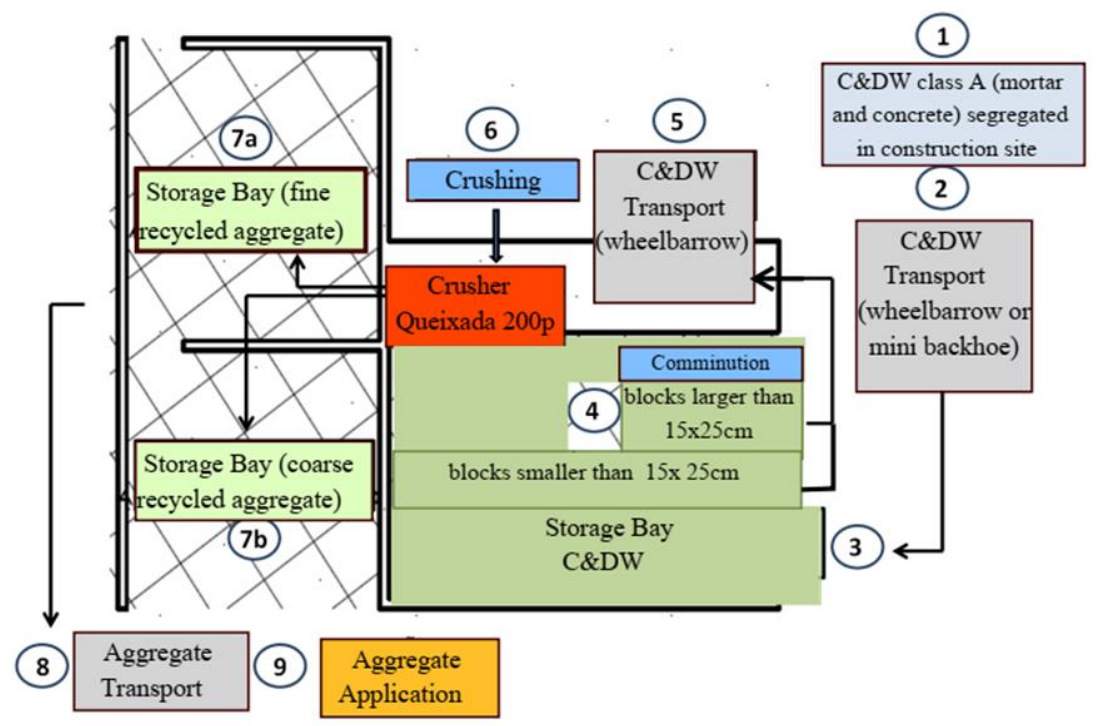

Figure 1. Layout of the small and decentralized recycling unit (SDRU) site in Bahia state, Northeast of Brazil. 
The flux was: the C\&DW Class A (mortar and concrete) segregated at the construction site (1) was transported using a mini backhoe or wheelbarrow (2) up to the storage bay (3). If necessary, this C\&DW was manually comminuted (4), since the crusher (Queixada 200p) has an inlet with a $15 \times 20 \mathrm{~cm}$ opening. Much more time is spent in the manual comminution of the C\&DW than in other stages of the process, such as transporting and feeding the Queixada.200p. This can be considered a limiting factor for the use of the SDRU. After this stage, the CD\&W was transported by wheelbarrow to the crushing equipment through an access ramp (5), as shown in Figure 1. The operation of the crusher is constant, that is, there is no interruption of the process for a new C\&DW load. This is an important aspect because the production of noise and dust is intense in the recycling area. The Queixada 200p is equipped with a set of sieves separating the coarse ( $7 b$ ) from the fine recycled aggregate (7a), which are then transported by gravity and stored in specific bays.

\subsection{Indicators of environmental and operational performance}

The selection of the environmental and operational performance indicators was conducted in two sequential and complementary steps. First, a review of the literature was performed considering the following criteria: (i) coherence with the object of study, (ii) technological, economic and temporal feasibility to measure the performance of the SDRU, (iii) elaborated from primary data, (iv) data or information from a reliable source. Yuan and Shen (2011) stated that the literature review is generally considered a key methodology for examining the development trend of research in a particular discipline. However, indicators should be chosen according to well-established scientific criteria and the validation step is imperative. Therefore, following the recommendations proposed by Bockstaller and Girardin (2003), end-use validation based on specialist judgment was applied in our study.

A total of 115 indicators of C\&DW recycling units performance were identified in the literature. From these, 48 referred to environmental aspects and 38 to operational performance. Most of these indicators are used for fixed units with a capacity above 100 tons per hour. We also identified 29 financial performance indicators that will not be addressed in this paper. First, those indicators that were similar or that did not fit the characteristics of an SDRU were excluded.

The ones chosen after that stage were submitted to the judgment of 13 experienced professional members of the National Research Network entitled: Methodologies and Technologies for the Sustainable Management of Solid Waste: Emphasis on the Reduction and Valorization in Urban Environment. These professionals answered the following question: Does this indicator allow the evaluation of the environmental, financial or operational performance of a decentralized and small C\&DW recycling unit? The answer was objective (yes/no); however, there was the possibility of including comments or suggestions. Performance indicators that obtained at least $50 \%$ approval were considered relevant after the validation step.

After the validation step, we collected primary and secondary data during nine consecutive months by daily monitoring of the SDRU at the construction site located in Bahia state, Brazil. The feasibility of obtaining data was analyzed regarding the availability, purpose, costs and adherence to the characteristics of the SDRU. After this evaluation, 4 (four) environmental performance indicators and 13 (thirteen) operational performance indicators were determined (Table 2). The environmental performance indicators represent the consumption of natural resources and energy, the generation of noise emissions and particulate matter. Meanwhile, the operational performance indicators represent productivity, inputs and outputs, worker training and safety, and physical structure. 
Table 2. Indicators selected for environmental and operational performance evaluation of the SDRU.

\begin{tabular}{|c|c|}
\hline \multicolumn{2}{|r|}{ Environmental performance } \\
\hline Indicator & Description \\
\hline Noise emission & Measurement of sound volume (decibels). \\
\hline Emission of particulates & $\begin{array}{l}\text { Mass of pollutant by volume of air }\left(\mu \mathrm{g} \cdot \mathrm{m}^{-3}\right) \text { measured during the production } \\
\text { of recycled aggregate. }\end{array}$ \\
\hline Water consumption & Volume consumed per volume of recycled aggregate $\left(\mathrm{L} \cdot \mathrm{m}^{-3}\right)$ \\
\hline Energy consumption & $\begin{array}{l}\text { Ratio between the SDRU's energy consumption and the total energy } \\
\text { consumption of the construction site. }\end{array}$ \\
\hline \multicolumn{2}{|r|}{ Operational performance } \\
\hline Indicator & Description \\
\hline $\begin{array}{l}\text { Maximum storage time of coarse } \\
\text { recycled aggregate }\end{array}$ & $\begin{array}{l}\text { Ratio between the volume of the storage bay and the coarse aggregate flow } \\
\text { rate }\left(\mathrm{m}^{3} \text { per day). }\right.\end{array}$ \\
\hline $\begin{array}{l}\text { Maximum storage time of fine } \\
\text { recycled aggregate }\end{array}$ & $\begin{array}{l}\text { Ratio between the volume of the storage bay and the fine aggregate flow rate } \\
\left(\mathrm{m}^{3} \text { per day }\right) .\end{array}$ \\
\hline $\begin{array}{l}\text { Percentage of time spent for } \\
\text { comminution }\end{array}$ & $\begin{array}{l}\text { Ratio between the comminution time of the C\&DW Class A and the total } \\
\text { crushing time (dimensionless). }\end{array}$ \\
\hline Feeding time of the crusher ${ }^{\mathrm{a}}$ & $\begin{array}{l}\text { Time taken to transport C\&DW class A between the storage bays and the } \\
\text { crusher feeding device (hour). }\end{array}$ \\
\hline Flow rate of C\&DW crushed & $\begin{array}{l}\text { Ratio of the C\&DW class A volume recycled and crusher operation effective } \\
\text { time }\left(\mathrm{m}^{3} \text { per hour). }\right.\end{array}$ \\
\hline $\begin{array}{l}\text { Percentage of coarse or fine } \\
\text { recycled aggregate obtained }\end{array}$ & $\begin{array}{l}\text { Ratio between the volume of coarse or fine aggregate and the total volume of } \\
\text { recycled aggregate produced in the crusher (dimensionless). We suggested } \\
\text { obtaining this indicator always at the end of the working day. }\end{array}$ \\
\hline Losses during the crushing process ${ }^{b}$ & $\begin{array}{l}\text { The complement of the ratio between the sum of volumes of coarse and fine } \\
\text { recycled aggregates and the volume of C\&DW (dimensionless). We } \\
\text { suggested obtaining this indicator always at the end of the working day. }\end{array}$ \\
\hline $\begin{array}{l}\text { Idleness of crushing equipment in a } \\
\text { working day }\end{array}$ & $\begin{array}{l}\text { Total time of interruption of the operation of the crushing equipment (hours). } \\
\text { Obtained by multiplying the number of interruptions by the duration of each } \\
\text { of these interruptions. We suggested obtaining this indicator always at the } \\
\text { end of the working day. }\end{array}$ \\
\hline $\begin{array}{l}\text { Total production time in a working } \\
\text { day }\end{array}$ & $\begin{array}{l}\text { The effective production time (hours). Obtained by the ratio between the sum } \\
\text { of the times spent with comminution, transportation, crushing, cleaning of } \\
\text { the equipment and organization of bays and the time of one working day. }\end{array}$ \\
\hline Training time & $\begin{array}{l}\text { Time expended for training the SDRU workers (hours). Obtained at the end } \\
\text { of a month of SDRU operation. }\end{array}$ \\
\hline Quality of raw material & $\begin{array}{l}\text { Ratio between the volume of the C\&DW Class A and the total volume of the } \\
\text { C\&DW discarded in the SDRU (dimensionless). }\end{array}$ \\
\hline $\begin{array}{l}\text { Existence of vibration control } \\
\text { mechanism requirement for worker } \\
\text { safety }\end{array}$ & Yes or no \\
\hline $\begin{array}{l}\text { Protection of raw material to ensure } \\
\text { crushing conditions. Requirement } \\
\text { to avoid rainfall over C\&DW }\end{array}$ & Yes or no \\
\hline \multicolumn{2}{|c|}{$\begin{array}{l}\text { a -The following should be taken into account: time to transport the C\&DW Class A from the waste } \\
\text { bays to the crusher, time of crushing operation, time to transport recycled aggregate from the crusher to } \\
\text { recycled aggregate storage bays, and time for clearing the sieve and organization of storage bays. }\end{array}$} \\
\hline \multicolumn{2}{|c|}{$\mathrm{V}_{1}-$ Volume of fine recycled aggregate } \\
\hline \multicolumn{2}{|c|}{$\mathrm{V}_{2}-$ Volume of coarse recycled aggregate } \\
\hline$V_{t}-$ Volume of C\&DW & \\
\hline
\end{tabular}


The environmental impacts related to the SDRU operation were also estimated using the Life Cycle Assessment (LCA) approach according to the ISO 14040 (ISO, 2006). It was considered that the recycled aggregate was to be used for the production of concrete without structural function. A comparison was made between the production of concrete $20 \mathrm{MPa}$ without structural function made manually from natural sand, gravel, cement and water, and the production of the same type of concrete but replacing the sand with fine recycled aggregate and the gravel with coarse recycled aggregate. During the elaboration of the Life Cycle Inventory (LCI), the C\&DW Class A, the energy consumption of the equipment, and the output of the emitted particulate material and the fine or coarse recycled aggregate were considered as inputs. The study covered only the phase of operation of the recycling equipment. The LCA was carried out using SimaPro ${ }^{\circledR}$ 8.0.1 PhD version. This is the advanced single-user version and is comparable to the business version SimaPro Analyst. The allocation was not used since the studied SDRU does not have co-functions. The background system boundary included data from materials, chemical and energy production from the Ecoinvent ${ }^{\circledR}$ Version 3.1 datasets, system model 'allocation, default' as a unit process, available in SimaPro 8.0.1® PhD version.

\subsection{Obtaining indicators and characterization of C\&DW and the recycled aggregate}

\subsubsection{Characterization of recycled aggregate}

The C\&DW Class A discarded in the storage area of the SDRU was characterized by visual observation and laboratory analyses following the recommendations and procedures published by the Brazilian Technical Standards. The gravimetric composition and grain-size distribution were determined and the unit mass (loose state) of the C\&DW was obtained by the examination of three duplicate aliquots from three different samplings. The fine and coarse recycled aggregates produced were characterized in order to indicate the possibility of their use for the production of concrete without structural function or for road and sidewalk paving. A composite sample was obtained by collecting 18 aliquots of $10 \mathrm{~kg}$ from the top, middle and bottom of each pile of recycled aggregate stocked at the storage bay.

One of the greatest difficulties for the application of recycled aggregates is due to its great variability. These materials have different mineralogical compositions and on full scale, there is no guarantee of adequate segregation of each type of C\&DW. Therefore, the recycled aggregate is heterogeneous and its variable composition makes it difficult to standardize its properties. Consequently, its use for making structural concrete is still controversial in Brazil and there is no technical guidance for this purpose.

\subsubsection{Noise emission}

The noise level emitted by the recycling equipment was measured using the method proposed by the Brazilian Technical Standards. Four points were selected in the SDRU, at the following locations: Point A, $1.5 \mathrm{~m}$ from the recycling equipment, the point closest to the sound source; Point $\mathrm{B}$, in the storage area of the $\mathrm{C} \& \mathrm{DW}$, in which the operator was working; Point $\mathrm{C}$, $4.2 \mathrm{~m}$ from the sound source and $2 \mathrm{~m}$ from the site boundary; and Point $\mathrm{D}, 2.0 \mathrm{~m}$ from the residences near the construction site.

\subsubsection{Emission of particulate matter}

A Berner impactor with a six-stage impaction sampler with different aperture diameters measured the emission levels of particulate matter. At each stage, particulate material compatible with the aperture of the equipment is retained in the membrane filters, which were weighed before and after the samplings in loco to determine the amount of particulate material. Four samplings were performed, three of them with the recycling equipment in operation and one with the equipment turned off.

The Brazilian Environmental Council uses the 24-hour period to establish concentration 
limits for Total Suspended Particles (TSP) and Inhalable Particles or Particulate Matter of up to $10 \mu \mathrm{m}$ (PM10). For the primary air quality, the TSP 24-hour average concentration limit of $240 \mu \mathrm{g} / \mathrm{m}^{3}$ of air is established, which may be exceeded only once per year. The amount of pollutant that, if exceeded, may affect the health of the population is considered a primary standard. For PM10, the maximum acceptable value of 24-hour average concentration is equal to $150 \mu \mathrm{g} \cdot \mathrm{m}^{-3}$ of air, and can likewise be surpassed only once a year.

\section{RESULTS AND DISCUSSION}

\subsection{SDRU environmental performance}

Based on the values measured at each point, it was possible to verify that at Point A, close to the crushing equipment, the highest levels of sound pressure were detected with an average of $81.6 \mathrm{~dB}$. According to the Brazilian legislation, this value is higher than the acceptable level of $55 \mathrm{~dB}$ for the daytime period in residential areas.

During the recycling process lasting six hours per day, there were emissions of TSP and PM10. Particles with a diameter between 14.9 and $4.9 \mu \mathrm{m}$ predominated in most samples. The highest value of particulate material sampling was $1,439 \mu \mathrm{g} . \mathrm{m}^{-3}$ and of TSP was $1,460 \mu \mathrm{m} \cdot \mathrm{m}^{-3}$. These values suggest that care should be taken to reduce the operator's exposure to particulate matter, since particles smaller than $10 \mu \mathrm{m}$ represent a risk factor for the development and worsening of cardiovascular and respiratory diseases.

In the study area, there was no water supply, and therefore its consumption was zero. A diesel generator provided the energy consumed by the crushing equipment (Queixada 200p). Table 3 shows some of the values of the environmental indicators obtained for the SDRU located at Bahia state, Brazil.

Table 3. Values of the indicators selected for environmental performance evaluation of the SDRU.

\begin{tabular}{lc}
\hline Indicator & Results \\
\hline Noise emission & $81.6 \mathrm{~dB}^{(\mathrm{a})}$ \\
Emission of particulate matter & $\mathrm{TSP}=1,460 \mu \mathrm{g} \cdot \mathrm{m}^{-3(\mathrm{~b})}$ \\
Water consumption & 0 \\
Energy consumption & $1.52 \times 10^{5} \mathrm{~kJ}$ \\
\hline
\end{tabular}

Notes: (a) Point A is closest to the equipment. (b) The results refer to a single sampling with three aliquots, taken over a period of six hours. The highest observed value is shown.

During the C\&DW recycling process, a performance indicator of losses equal to $8 \%$ was obtained. It is possible to say that from $100 \mathrm{~kg}$ of C\&DW that enters the equipment, $92 \mathrm{~kg}$ is recovered as recycled aggregates, of which $60 \%$ corresponds to coarse aggregate and $40 \%$ to fine. The total time of equipment operation was of 86.9 hours and, knowing that the equipment consumed $3 \mathrm{~kW}$ per hour, it was possible to calculate the total energy consumption during the period. These values were considered to draw up the LCI of the recycled aggregate production in the crushing equipment (Table 4).

The results are applicable only for the considerations and assumptions made for this LCA study. The result of comparison of the production of $1.0 \mathrm{~m}^{3}$ concrete without structural function, using the ILCD 2011 Midpoint V1.07 / EU27 2010 method, is presented in Figure 2. 
Table 4. SDRU's Life Cycle Inventory.

\begin{tabular}{lc}
\hline Output & Total \\
\hline Fine recycled aggregate & $97,539.2 \mathrm{~kg}$ \\
Coarse recycled aggregate & $144,931.8 \mathrm{~kg}$ \\
Emissions to air & \\
Particulates & $52.7 \mathrm{mg}$ \\
Input (electricity) & \\
Electricity, low voltage & $260.8 \mathrm{~kW}$ \\
\hline
\end{tabular}

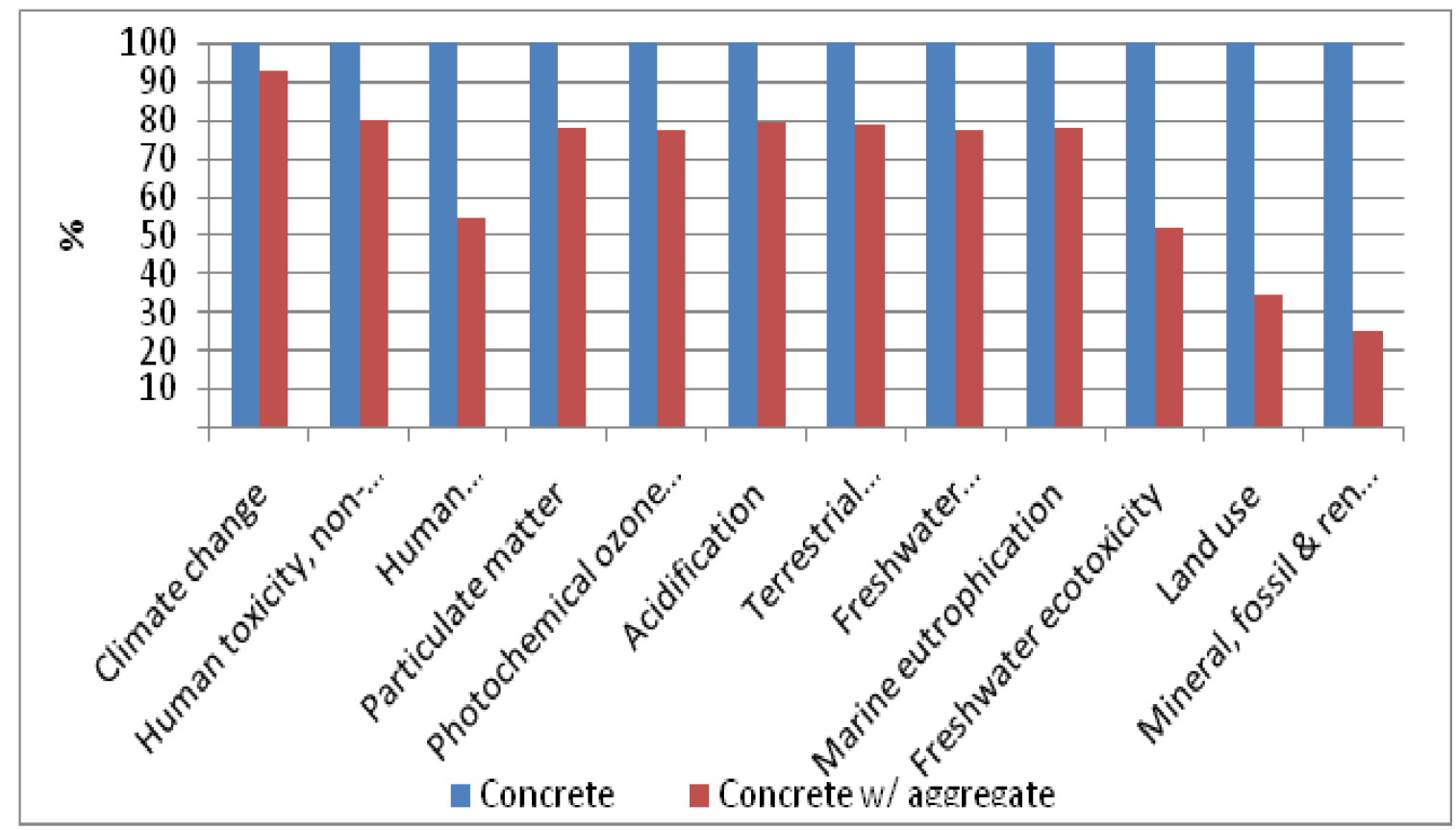

Figure 2. Comparison of the Life Cycle Impact Assessment between conventional concrete without structural function and the same material manufactured with recycled aggregate.

It is possible to state that there was a decrease of environmental impacts in all the categories considered. This is due to the reduction in the consumption of natural resources and energy for the extraction of natural sand and gravel, which have a greater impact potential than the energy consumption and emission of particulate material from the SDRU. The categories with the greatest potential environmental impact reduction were "Land Use", and "Depletion of Mineral Resources". Considering these categories, the contribution of gravel and sand to the impact potential was greater than $60 \%$. Therefore, using the recycled aggregate to replace these materials has been proven to be environmentally positive.

Guinot et al. (2015) also found a reduction of environmental impacts in the recycling of construction and demolition waste in all impact categories analyzed in their LCA study. However, the authors caution that these gains may vary with the transport distance between the generating source and the recycling unit. Generally, LCA studies based on real-scale data show an increase in environmental impacts mainly due to the transport of C\&DW to a large and centralized recycling facility. The LCA developed by Penteado et al. (2015) on the recycling of construction and demolition waste from small generators has shown that the environmental impacts resulting from the transport of this material over great distances can make the losses greater than the environmental gains. Therefore, considering the reality of developing countries, it is necessary to overcome the main obstacles to the decentralization of C\&DW recycling, such as: prediction of the use of recycled aggregates in the design phase, rigorous segregation in the 
generating source, technological innovation aimed to reduce the costs of implementation and operation of the SDRU, and technical standardization considering the local reality and technical expertise.

The result of normalization for the production of $1 \mathrm{~m}^{3}$ of concrete without structural function using the ILCD 2011 Midpoint V1.07 / EU27 2010 method is shown in Figure 3. Considering the manufacture of conventional concrete without structural function, the results confirm that the most relevant category was the "Depletion of Mineral Resources" due to the impact of natural sand and gravel extraction. Using the fine and coarse recycled aggregate, the most relevant category was "Climate Change", due to the impact of cement production.

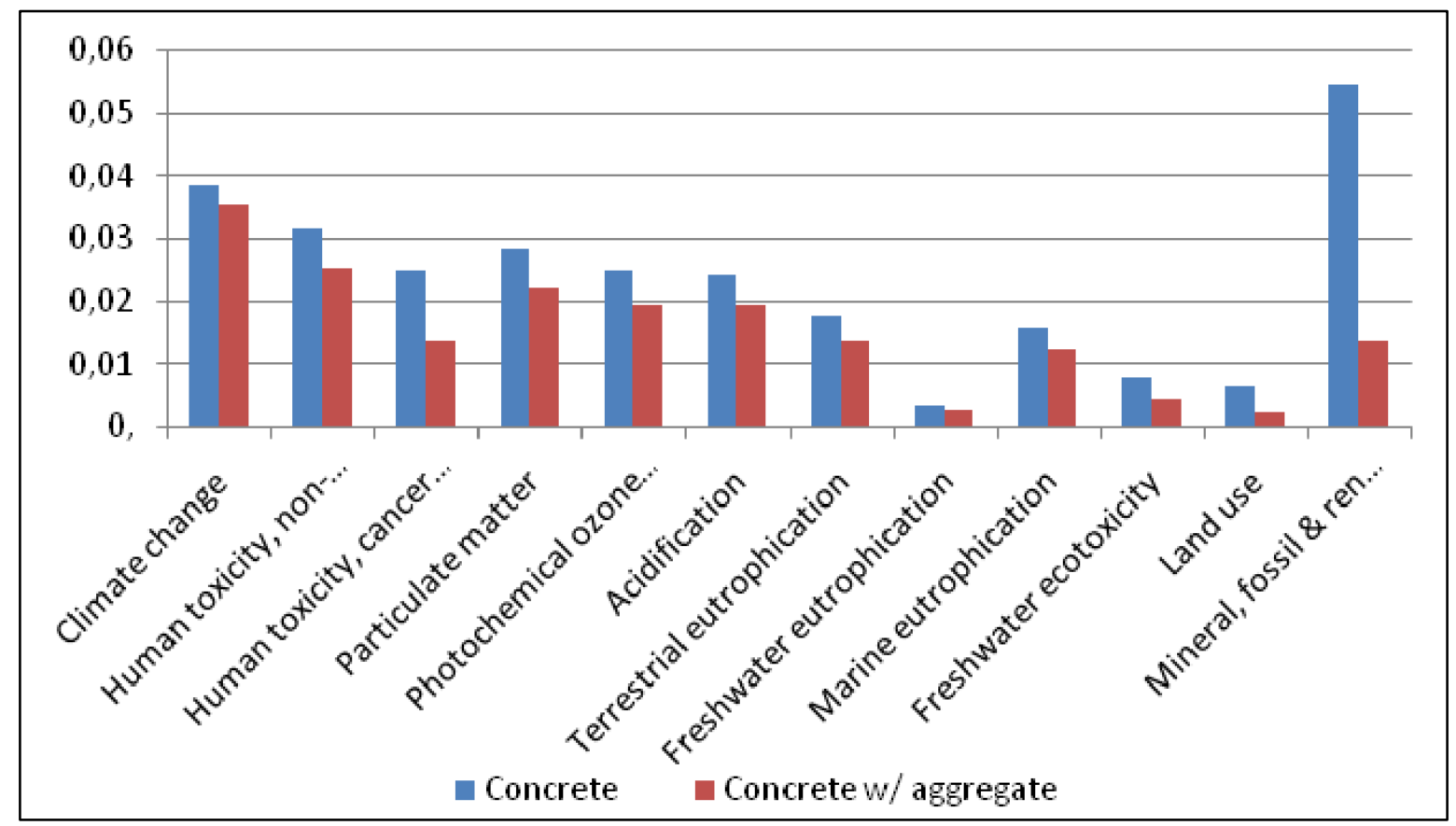

Figure 3. Result of the standardization and comparative analysis between conventional concrete without structural function and the same material manufactured with recycled aggregate.

It is important to note that most of the environmental impacts shown in Figure 4 come from the use of Portland cement. More research is needed to investigate the importance of using industrial by-products such as blast furnace slag to replace part of the clinker for Portland cement production. However, it is also important to emphasize that the transportation to cement industries can increase the environmental impacts rather than reduce them.

a)

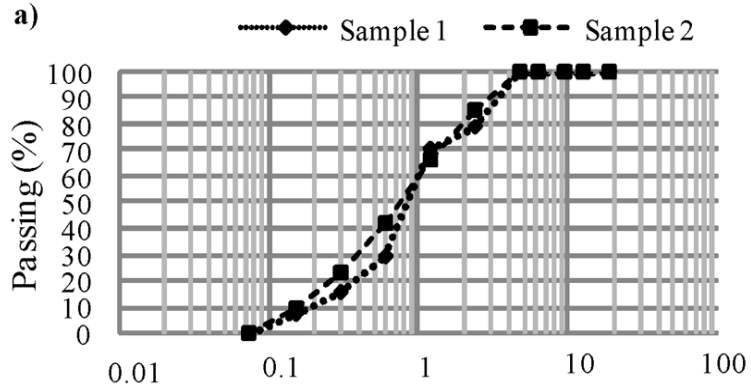

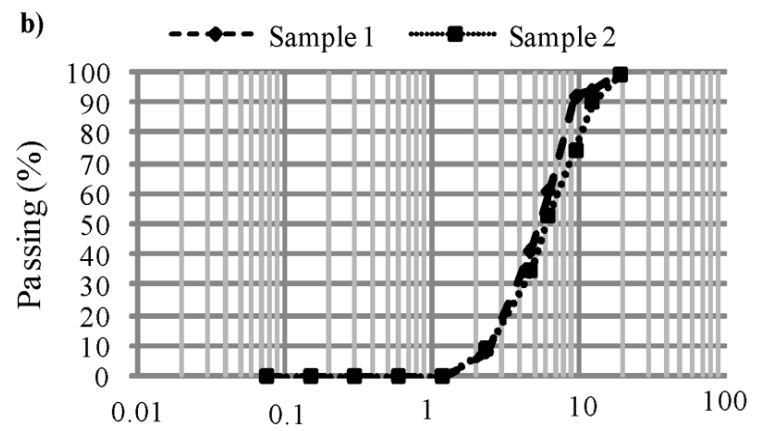

Figure 4. Grading curves of recycled aggregates. a) Fine aggregate; b) coarse aggregate.

The electricity used to extract or produce construction materials such as Portland cement came from the Ecoinvent ${ }^{\circledR}$ database, which takes into account the European energy matrix based 
on fossil fuels. This is an important limitation of our study and should be taken into account by decision-makers. To reduce the uncertainty of the LCA studies conducted in Brazil requires the construction of a Brazilian database. Although difficult and time-consuming, this task must be progressively accomplished. The standardization confirmed the environmental gain by using recycled aggregate rather than natural sand and gravel for the production of concrete.

\subsection{Operational performance indicators}

The values of the operational performance indicators are shown in Table 5. The degree of segregation of raw material (C\&DW) was very high. Only $0.05 \%$ of other wastes were not mortars and concrete. This is a crucial step in making the process attractive from the economic and financial point of view and is also a challenge, since the labour in the construction sector is very unqualified in Brazil. It should be mentioned that the SDRU installed in Bahia state has only one operator, who has not received training for all activities.

Table 5. Values of the indicators selected for operational performance evaluation of the SDRU.

\begin{tabular}{lc}
\hline Indicator & Results \\
\hline Maximum storage time of coarse recycled aggregate & 15 days \\
Maximum storage time of fine recycled aggregate & 25 days \\
Percentage of the time spent for comminution & $2.5 \%$ \\
Feeding time of the crusher & $0.73 \mathrm{~h}$ \\
Flow rate of C\&DW crushed & 0.5 to $1.1 \mathrm{~m}^{3}$ per hour \\
Percentage of coarse recycled aggregate obtained & $60.6 \%$ \\
Percentage of fine recycled aggregate obtained & $39.4 \%$ \\
Losses during the crushing process & $8 \%$ \\
Idleness of crushing equipment in a working day(a) & $2.4 \mathrm{~h}$ \\
Total production time in a working day ${ }^{(\mathrm{a})}$ & $4.3 \mathrm{~h}$ \\
Training time & No training was performed \\
Quality of raw material & $0.05 \%$ \\
Existence of vibration control mechanism requirement for worker safety & No \\
Protection of raw material to ensure crushing conditions. & No \\
\hline
\end{tabular}

Note: (a) 8-hour working day.

The productivity of the crusher varied between 50 and $100 \%$ of the nominal capacity. This range was due to the irregularity of the C\&DW input flow. The time spent in transporting the C\&DW by wheelbarrow corresponded to $17 \%$ of the total time of production. Besides, other interruptions such as the verification of the electrical installations, the need to clean the C\&DW storage site, and the necessity for the operator to perform other activities outside the SDRU contributed to the idleness of the crushing machine. It was verified that there is no vibration control mechanism recommended to give greater protection to the operator's health. Improvements such as using treadmills or a team with two operators would allow a productivity gain.

The recycled aggregates produced were destined for several purposes, such as the manufacture of concrete blocks, use in the execution of the subfloor, and the production of concrete without structural function, among others. The recycled aggregates could be used at 
the construction site, generating savings on the acquisition of natural aggregates and minimizing the environmental impacts associated with the transport of this material.

\subsection{C\&DW and recycled aggregate characterization}

The C\&DW unit mass was equal to $978.5 \pm 30.4$. Only large pieces of precast concrete blocks, concrete and fine materials like sand, gravel, soil and cement were found in the C\&DW aliquots collected. Preliminary classification tests showed that $40 \%$ of the C\&DW presented dimensions smaller than $75 \mathrm{~mm}$. Therefore, the comminution step is imperative because there is an incompatibility between the size of the C\&DW and the feed device of the crusher. The low content of contamination and the small grain-size variability of the C\&DW are important characteristics, since they allow the production of aggregates with greater homogeneity and uniformity.

The Brazilian Technical Standards provide the requirements for the use of recycled aggregates in road paving and concrete without structural function, based on physical and chemical aspects such as grain-size composition, maximum characteristic size, shape index, material that passes through a $0.42 \mathrm{~mm}$ sieve, contaminant content, water absorption, cement and rock, the California Support Index and expansibility. Figure 4 shows the grain-size distribution curves of the evaluated aliquots.

The particle-size distribution of the coarse recycled aggregate samples partially adapts to the 4.75-12.5 $\mathrm{mm}$ zone, these being considered the optimum dimensions for concrete manufacturing. The samples of fine recycled aggregate were classified as average sand. A test to obtain the content of material that would pass through the $0.42 \mathrm{~mm}$ sieve is required for the use of the recycled aggregate in road paving and was carried out only for the fine recycled aggregate samples. The results $(24.85 \%$ and $27.93 \%)$ were considered acceptable according to the Brazilian Technical Standards.

The recycled aggregate from the SDRU does not present non-mineral material contents. The specific mass varied between 2,527 and 2,550 g.cm ${ }^{-3}$ and the maximum value of the water absorption was equal to $7.72 \%$. These results meet the requirements for recycled aggregate used for manufacturing concrete without structural function. However, the fine recycled aggregate presented a high content of clay and friable materials, and was therefore not suitable for this use.

On the other hand, the coarse aggregate presents values lower than $2 \%$ and there is no restriction for its application. The presence of powdery material was adequate and the average value of the shape index was 2.04, which indicates a lamellar format. The contents of soluble salts, chlorides and sulphates were below $1 \%$.

Table 6 shows a summary of the information regarding the compliance with the Brazilian Technical Standards requirements. These results show that the aggregates obtained from the SDRU have great potential for use and valorization. Regarding the clay content found in the samples of fine aggregates, the possibility of contamination during the storage of the material cannot be disregarded.

\section{CONCLUSIONS}

Most of the environmental, economic or operational performance indicators of C\&DW recycling units have been defined and obtained for facilities with a capacity exceeding 100 tons per hour. From a critical review of the literature, validated by the judgment of specialists, it was concluded that, out of a total of 115 indicators, only 17 are applicable to small and decentralized C\&DW recycling facilities. 
Table 6. Summary of the characterization results of the recycled aggregates from SDRU.

\begin{tabular}{|c|c|c|c|c|c|c|}
\hline Criteria & $\begin{array}{c}\text { Fine } \\
\text { Aggregate }\end{array}$ & $\begin{array}{c}\text { Fine } \\
\text { Aggregate }\end{array}$ & $\begin{array}{c}\text { Coarse } \\
\text { Aggregate }\end{array}$ & $\begin{array}{c}\text { Coarse } \\
\text { Aggregate }\end{array}$ & \multicolumn{2}{|c|}{ Brazilian Technical Standards } \\
\hline & & & & & $\begin{array}{l}\text { Paving } \\
\text { (roads, sidewalks, } \\
\text { among others) }\end{array}$ & $\begin{array}{l}\text { Concrete without } \\
\text { structural function }\end{array}$ \\
\hline Material that passes through $0.42 \mathrm{~mm}$ sieve & ok & ok & n.a. & n.a. & $10-40 \%$ & n.a \\
\hline $\begin{array}{l}\text { Mass of non-mineral materials (organics } \\
\text { including plastics, wood, gypsum, glass, } \\
\text { among others) }\end{array}$ & ok & ok & ok & ok & $\leq 3 \%$ & $\leq 2 \%$ \\
\hline Water absorption* & ok & ok & ok & ok & n.a. & $\leq 7 \%$ \\
\hline Maximum characteristic size & ok & ok & ok & ok & $\leq 63 \mathrm{~mm}$ & n.a. \\
\hline Powdery material & ok & ok & ok & ok & n.a. & $\leq 10 \%$ \\
\hline Shape index & n.a. & n.a. & not ok & not ok & $\leq 3.0$ & $\leq 3.0$ \\
\hline Clay and friable materials & ok & ok & ok & ok & n.a. & $\leq 2 \%$ \\
\hline Salts, chlorides and sulphates. & ok & ok & n.a. & n.a. & n.a. & $\leq 1 \%$ \\
\hline California Support Index** & ok & ok & not ok & not ok & $\geq 20 \%$ & n.a. \\
\hline Expansibility** & ok & ok & not ok & not ok & $\leq 1.0 \%$ & n.a. \\
\hline
\end{tabular}

Note: n.a.: not applicable; *Fine recycled aggregate (water absorption $\leq 12 \%$ ); **Requirements for use as road sub-base. 
The monitoring of the C\&DW recycling process for nine consecutive months, applying the selected indicators, allowed us to verify that the emission of particulate matter is one of the critical points. Some control measures need to be taken to ensure the safety of the operators of these small and decentralized C\&DW recycling units in order to avoid the risk of the development of cardiovascular and respiratory diseases.

Applying the Life Cycle Assessment approach, it was concluded that the use of the recycled aggregate in the manufacture of concrete without structural function resulted in a decrease of environmental impacts in all the categories considered. The most relevant category was the "Depletion of Mineral Resources" compared to the impact of natural sand and gravel extraction.

The coarse aggregate samples analyzed met the requirements of the Brazilian Technical Standards for manufacturing concrete without structural function, even though they did not present optimal characteristics. The results allow us to state that the recycled aggregates obtained from the SDRU have great potential for use and valorization. However, the benefits of C\&DW recycling can be significantly affected, if the transport distance between the generating source and the SRDU is very large.

The SRDU can be a source of production and reinsertion of materials at the local level. Therefore, this initiative can be attractive since it reduces negative environmental impacts associated with the extraction, transport and use of the natural aggregates. Besides, there are significant social and environmental impacts when C\&DW is inadequately disposed of in solid waste dumps. In addition, C\&DW valorization promotes a circular economy, job creation and business opportunities. However, there is limited interest in the use of recycled aggregates in the Brazilian construction sector. One of the reasons is the lack of information about the ecoefficient recycling process and the quality of the recycled aggregate

\section{ACKNOWLEDGMENTS}

The authors would like to thank the Foundation for Research Support of the State of Bahia (FAPESB), the National Council for Scientific and Technological Development (CNPq) and the Financier of Studies and Projects (FINEP) for the provision of scholarships and financial support that made it possible to carry out this research.

\section{REFERENCES}

ABNT. NBR 10004. Rio de Janeiro, 2004. Available only in Portuguese on: https://vigilanciasanitaria.sc.gov.br/index.php/download. Access: 10 Feb. 2018.

BOCKSTALLER, C.; GIRARDIN, P. How to validate environmental indicators. Agricultural Systems, Amsterdam, v. 76, p. 639 - 653, 2003. https://doi.org/10.1016/S0308521X(02)00053-7

BRASIL. Presidência da República. Lei n. 12.305, de 05 de agosto de 2010. Institui a Política Nacional de Resíduos Sólidos; altera a Lei no 9.605, de 12 de fevereiro de 1998; e dá outras providências. Diário Oficial [da] União: seção 1, Brasília, DF, 03 ago. 2010.

CONAMA (Brasil). Resolução $n^{\circ}$ 307, de 5 de julho de 2002. Estabelece diretrizes, critérios e procedimentos para a gestão dos resíduos da construção civil. Diário Oficial [da] União: seção 1, Brasília, DF, n. 136, p. 95-96, 17 jul. 2002.

EUROPEAN CIRCLE ECONOMY. The Circularity Gap Report. Amsterdam, 2019. Available on: https://circulareconomy.europa.eu/platform/sites/default/files/circularity_gap_report_20 19.pdf. Access: 02 Apr. 2021. 
FATTA, D.; PAPADOPOULOS, A.; AVRAMIKOS, E.; SGOUROU, E.; MOUSTAKAS, K.; KOURMOUSSIS, F. et al. Generation and management of construction and demolition waste in Greece - an existing challenge. Resource Conservation and Recycling, v. 40, n. 1, p. 81-91, 2003. https://doi.org/10.1016/S0921-3449(03)00035-1

GUIGNOT, S.; TOUZÉ, S.; VON DER WEID, F.; MÉNARD, Y.; VILLENEUVE, J. Recycling Construction and Demolition Wastes as Building Materials: A Life Cycle Assessment. Journal of Industrial Ecology, v. 19, n. 6, p. 1030 - 1043, 2015. https://doi.org/10.1111/jiec.12262

HERTWICH, E. G.; ALI, S.; CIACCI, L.; FISHMAN, T.; HEEREN, N.; MASANET, E. et al. Material efficiency strategies to reducing greenhouse gas emissions associated with buildings, vehicles, and electronics - A Review. Environmental Research Letters, v. 14, n. 4, 2019. https://doi.org/10.1088/1748-9326/ab0fe3

HUANG, B.; WANG, X.; KUA, H.; GENG, Y.; BLEISCHWITZ, R.; REN, J. Construction and demolition waste management in China through the $3 \mathrm{R}$ principle. Resource $\begin{array}{llllllll}\text { Conservation and Recycling, } & \text { v. } 129, \quad \text { p. } 36 & - & 44,\end{array}$ https://doi.org/10.1016/j.resconrec.2017.09.029

IBGE. National Survey of Basic Sanitation. 2015. Available only in Portuguese on: https://sidra.ibge.gov.br/pesquisa/pnsb. Access: 02 Mar. 2018.

ISO. ISO14040:2006: Environmental Management. Life Cycle Assessment. Principle and Framework. Geneva, 2006.

JIMÉNEZ-RIVERO, A.; GARCÍA-NAVARRO, J. Exploring factors influencing postconsumer gypsum recycling and landfilling in the European Union. Resources, Conservation and Recycling, v. 116, p. $116-123,2017$. https://doi.org/10.1016/j.resconrec.2016.09.014.

KOLAVENTI, S. S.; TEZESWI, T. P.; SIVA KUMAR, M. V. N. An assessment of construction waste management in India: A statistical approach. Waste Management and Research, v. 38, n. 4, p. 444-459, 2019. https://doi.org/10.1177/0734242X19867754

LENTON, T. M.; ROCKSTRÖM, J.; GAFFNEY, O.; RAHMSTORF, S.; RICHARDSON, K.; STEFFEN, W. et al. Climate tipping points - too risky to bet against. Nature, v. 575, p. 592 - 595, 2020. https://doi.org/10.1038/d41586-019-03595-0

PENTEADO, C. S. G.; ROSADO L. P.; LOPES, A. A. 2015. Life Cycle Assessment of Construction And Demolition Wastes From Small Generators. In: FIFTEENTH INTERNATIONAL WASTE MANAGEMENT AND LANDFILL SYMPOSIUM, 5-9 oct. 2015. San Margherita di Pula, Cagliari, Italy. Proceedings Sardinia 2015. Cagliari, 2015, p. 41-50.

PONNADA, M. R.; KAMESWARI, P. Construction and Demolition Waste Management - A Review. International Journal of Advanced Science and Technology, v. 84, p. 19 46, 2016. http://dx.doi.org/10.14257/ijast.2015.84.03

SERGEEVA, N.; LINDKVIST, C. Narratives of innovation that address climate change agenda in the construction sector. In: HAVENVID, M. I.; LINNÉ, A.; BYGBALLE, L. E.; HARTY, C. (eds.). The connectivity of innovation in the construction industry. London: Taylor \& Francis, 2019. p. 288-303. 
YUAN, H.; SHEN, L. Trend of the research on construction and demolition waste management. $\begin{array}{llllllll}\text { Waste Management, } & \text { v. } & 31, & \text { p. } & 670 & - & 679,\end{array}$ https://doi.org/10.1016/j.wasman.2010.10.030 